Article

\title{
Cryoprotective Roles of Carboxymethyl Chitosan during the Frozen Storage of Surimi: Protein Structures, Gel Behaviors and Edible Qualities
}

\author{
Xiangwei Zhu ${ }^{1, * \mathbb{D}}$, Minglang Zhu ${ }^{1}$, Diheng He ${ }^{1}$, Xueyin Li $^{1}$, Liu Shi ${ }^{2}$, Lan Wang ${ }^{2}$, Jianteng Xu ${ }^{3}$, Yi Zheng ${ }^{3}$ \\ and Tao Yin $4, *$
}

check for updates

Citation: Zhu, X.; Zhu, M.; He, D.; Li, X.; Shi, L.; Wang, L.; Xu, J.; Zheng, Y.; Yin, T. Cryoprotective Roles of Carboxymethyl Chitosan during the Frozen Storage of Surimi: Protein Structures, Gel Behaviors and Edible Qualities. Foods 2022, 11, 356. https://doi.org/10.3390/ foods11030356

Academic Editors: Jianhua Xie, Yanjun Zhang and Hansong Yu

Received: 24 December 2021

Accepted: 24 January 2022

Published: 26 January 2022

Publisher's Note: MDPI stays neutral with regard to jurisdictional claims in published maps and institutional affiliations.

Copyright: (c) 2022 by the authors. Licensee MDPI, Basel, Switzerland. This article is an open access article distributed under the terms and conditions of the Creative Commons Attribution (CC BY) license (https:// creativecommons.org/licenses/by/ $4.0 /)$.
1 National "111" Center for Cellular Regulation and Molecular Pharmaceutics, Key Laboratory of Fermentation Engineering (Ministry of Education), Hubei Key Laboratory of Industrial Microbiology, Hubei University of Technology, Wuhan 430068, China; datouzhu1216@163.com (M.Z.); hdiheng@163.com (D.H.); xiali12282021@163.com (X.L.)

2 Institute for Farm Products Processing and Nuclear-Agricultural Technology, Hubei Academy of Agricultural Science, Wuhan 430064, China; shiliu_hzau@163.com (L.S.); lilywang_2016@163.com (L.W.)

3 Department of Grain Science and Industry, Kansas State University, Manhattan, KS 66506, USA; jianteng@ksu.edu (J.X.); yzheng@ksu.edu (Y.Z.)

4 College of Food Science and Technology, Huazhong Agricultural University, Wuhan 430070, China

* $\quad$ Correspondence: xiangwei@ksu.edu (X.Z.); yintao@mail.hzau.edu.cn (T.Y.); Tel.: +86-182-7189-3897 (X.Z.)

\begin{abstract}
Carboxymethyl chitosan (CMCh) is an ampholytic chitosan derivative that manifests versatile applications in food industry, such as antibacterial ingredients and nutritional additives. However, its use as a cryoprotectant remains under-researched. In this study, the cryoprotective effect of $\mathrm{CMCh}$ oligosaccharide (CMCO) on frozen surimi (silver carp) was systematically investigated in terms of protein structures, gelling behaviors, and sensory qualities. $\mathrm{CMCO}(0.6 \%)$ was incorporated in the surimi before frozen storage $\left(-18{ }^{\circ} \mathrm{C}\right.$ for 60 days) while the commercial cryoprotectant $(4 \%$ sucrose, $4 \%$ sorbitol) was used as a positive control. Results indicated that CMCO could inhibit the freezing-induced denaturation of myofibrillar protein, whose values of solubility, $\mathrm{Ca}^{2+}$-ATPase and sulfhydryl content were $24.8 \%, 64.7 \%$, and $17.1 \%$ higher than the nonprotected sample, respectively, while the surface hydrophobicity was $21.6 \%$ lower. Accordingly, CMCO stabilized microstructure of the surimi gels associated with improved gel strength, viscoelasticity, water-holding capacities, and whiteness. Moreover, the cryoprotective effect of CMCO with higher degree of carboxymethyl substitution (DS: 1.2) was more pronounced than that of low-DS-CMCO (DS: 0.8). Frozen surimi treated with high-DS-CMCO achieved competitive gelling properties and sensory acceptability to those with the commercial counterpart. This study provided scientific insights into the development of ampholytic oligosaccharides as food cryoprotectants.
\end{abstract}

Keywords: carboxymethyl chitosan; frozen surimi; myofibrillar protein; denaturation; gelling properties

\section{Introduction}

Surimi is a reconstituted food used for the production of various seafood dishes, such as fish balls, cakes, and croquettes [1,2]. Among all ingredients of the fish muscle, myofibrillar protein (MP), a salt-soluble protein, is mainly responsible for surimi functionalities [3]. Like other uncured meats, the shelf life of surimi is largely depending on frozen storage [3-5], which restrains intrinsic enzyme activities, microbial growth, and lipid oxidation of surimi during long-term preservation [6,7]. However, undesirable quality deteriorations still occur (e.g., water loss, structural weakening, and nutrition decay), and most of them are related to MP denaturation [8], which owes to the effect of ice crystallization, protein concentration and oxidation [9]. 
To address those problems, appropriate uses of food-grade cryoprotectants are necessary [10]. Given the unexpected taste or high caloric values of commercial cryoprotectants, such as sugars, polyols, and phosphates [11], research interest shifted to other natural additives derived from food proteins and saccharides. Among which, oligosaccharides, i.e., carrageenan oligomer [12], cellobiose [13], and konjac oligo-glucomannan [14] etc., have drawn particular attentions owing to their pronounced health benefits and consumer acceptability [15].

Oligosaccharides function as cryoprotectants through: (1) inhibiting ice recrystallization in frozen surimi and reducing physical damages to MP structures [9], (2) forming saccharide-MP binary complex to prevent MP from freezing-induced aggregation [16]. It is noteworthy that both ice-inhibition and complexation effects of saccharides were dependent on their strong polarities $[9,17]$. Therefore, some intrinsic structural characteristics, such as the charge properties, of exogenous oligosaccharides are believed to govern their cryoprotective effects. For example, Zhang et al. [18,19] reported that alginate oligosaccharide and trehalose could prevent the freezing denaturation of myosin. Though both saccharides exhibited the same degree of polymerization ( $\mathrm{DP}=2 \mathrm{n})$, the charged alginate oligomer had stronger protecting effect than the noncharged trehalose.

Chitosan is an acid-soluble cationic polysaccharide that has been widely used as food additives [20,21]. To improve its solubility in water, carboxymethylation is mostly carried out [22]. The derived carboxymethyl chitosan (CMCh, Figure S1) is a typical ampholytic polysaccharide [23,24]. It demonstrates outstanding moisture-retention capacity [22], which is the key to regulate the water state and ice crystallization at subzero temperatures. Furthermore, the ampholytic structure of saccharide was also reported to be effective in modulating the protein aggregation [25]. On the basis of these observations, the ampholytic $\mathrm{CMCh}$ was a potential cryoprotectant to proteins. However, the development of CMChbased additives remained less in frozen food when compared with other charged or neutral saccharides, such as chitosan (+), carrageenan (-), and konjac glucomannan (nonionic) $[26,27]$. Thus, the objective of this study is to: (1) investigate how the ampholytic structure of $\mathrm{CMCh}$ influences its cryoprotective effect to frozen surimi proteins, and (2) evaluate the edible properties of obtained surimi gels.

Since the functional properties of charged saccharides are highly related to their charge densities [25,26], CMCh with different degrees of carboxymethyl substitution (DS) were selected as cryoprotectants in this study, which were hydrolyzed to oligosaccharides and added to surimi before freezing. The storage stability of MP was thoroughly characterized, while the gelling behaviors and edible qualities of frozen surimi were also evaluated, including the rheological properties, microstructures, mechanical strength, water-holding capacities, sensory scores, and whiteness. This work aims at a paradigm shift for the development of ampholytic oligosaccharides as high-performance cryoprotectants for aquatic food preservations.

\section{Materials and Methods}

\subsection{Materials}

Alive farm raised-silver carp (Hypophthalmichthys molitrix, weighing $2.0 \pm 0.1 \mathrm{~kg}$ ) were purchased from a local market (Wuhan, China), transported to laboratory within 15 min, and subjected to percussive stunning. Carboxymethyl chitosan with two different DS, CMCh-A and -B, were kindly donated by Haobo biotech Corp (Henan, China). The DS values of CMCh-A and -B were characterized to be 0.8 and 1.2 by using the potentiometric titration [28]. Both CMCh exhibited similar molecular weight $\left(\mathrm{M}_{\mathrm{W}}\right)$ at about $6.02 \times 10^{4} \mathrm{Da}$. Chitosanase, with an activity unit at 200,000 U/g, was purchased from Shengda biotech Corp (Henan, China). All other chemicals were purchased from Aladdin Bio-chem Technology Co., LTD (Shanghai, China). Ultrapure water was used in all experiments unless specified otherwise. 


\subsection{Preparation of $\mathrm{CMCh}$ Oligosaccharide}

The $\mathrm{CMCh}$ oligosaccharide (CMCO) was prepared according to previous studies with some modifications [29,30]. Briefly, $500 \mathrm{~mL}$ of CMCh solution $(10 \mathrm{mg} / \mathrm{mL})$ was prepared at $\mathrm{pH} 5$, and an aliquot of $60 \mathrm{mg}$ chitosanase was added into the solution. The hydrolysis reaction was carried out at $50{ }^{\circ} \mathrm{C}$ for $5 \mathrm{~h}$ and terminated by heating the mixture at $100{ }^{\circ} \mathrm{C}$ for $10 \mathrm{~min}$. The obtained solution was neutralized, filtered, and concentrated with a vacuum rotary evaporator (IkA-Works Inc., Staufen, Germany). Then, the hydrolysate was precipitated by mixing with 10 volumes of ethanol. After being redissolved in the water, the solution was filtered through a polymer membrane (Mw cut-off: $10 \mathrm{KDa}$ ) and the filtrates were lyophilized. The average DP for both CMCO-A and CMCO-B was characterized to be approximately 6.8 , as reflected by the contents of reducing sugars.

\subsection{Preparation of Frozen Surimi}

The frozen surimi was prepared according to Zhangt et al. [31]. The fish was killed and its head, scales and internal organs were removed. Fresh fish meat was cut and washed three times by five volumes of distilled ice water. Then, the surimi was dispersed in $0.5 \% \mathrm{NaCl}$ solution at the ratio of $1: 2(w / v)$ and dehydrated with nylon net to reach a final moisture content at $78 \%$. The protein content in surimi was determined to be $15.2 \%$ through the Kjeldahl method. The obtained surimi was added with CMCO-A (0.6\%), CMCO-B $(0.6 \%)$ or commercial cryoprotectant ( $4 \%$ sucrose and $4 \%$ sorbitol), respectively, and packaged in polyethylene bags with the size of $20 \times 15 \times 2 \mathrm{~cm}^{3}$. Surimi without any cryoprotectant added was set as a blank control. All samples were frozen at $-18^{\circ} \mathrm{C}$ in air (with a freezing rate of $1.2{ }^{\circ} \mathrm{C} / \mathrm{min}$ ) and conditioned overnight to achieve uniform initial temperatures. Then, the surimi was transferred to a freezer and stored at $-18{ }^{\circ} \mathrm{C}$ for 0 , $10,20,30,45$ and 60 days. The frozen surimi was thawed at $4{ }^{\circ} \mathrm{C}$ for $20 \mathrm{~h}$ before further analysis.

\subsection{Characterizations of MP in Frozen Surimi}

\subsubsection{Content of Salt-Soluble Protein}

$\mathrm{MP}$ of the surimi was prepared by following the processes of Lin et al. with modifications [7]. Frozen surimi (5 g) was mixed with $45 \mathrm{~mL}$ of $0.6 \mathrm{M} \mathrm{KCl}$ solution (pH 7.0) and homogenized at $9000 \mathrm{rpm}$ for $100 \mathrm{~s}$ (an operation of $20 \mathrm{~s}$ with an interval of $15 \mathrm{~s}$ ). The homogenate was conditioned in an ice water bath for $30 \mathrm{~s}$ and centrifuged at $9000 \mathrm{rpm}$, $4{ }^{\circ} \mathrm{C}$ for $20 \mathrm{~min}$. The supernatant was collected and mixed with three volumes of cold deionized water followed by centrifugation at $6000 \mathrm{rpm}, 4^{\circ} \mathrm{C}$ for $20 \mathrm{~min}$. The precipitate was re-suspended in $20 \mathrm{~mL}$ of $0.6 \mathrm{M} \mathrm{KCl}$ solution and centrifuged again at $6000 \mathrm{rpm}, 4^{\circ} \mathrm{C}$ for $20 \mathrm{~min}$. Finally, content of salt-soluble protein in the supernatant was determined by the Biuret method.

\subsection{2. $\mathrm{Ca}^{2+}$-ATPase Activity}

$\mathrm{Ca}^{2+}$-ATPase activity was determined according to Liu et al. [14]. Briefly, the $\mathrm{Ca}^{2+}$ ATPase assay was performed at $37^{\circ} \mathrm{C}$ for $10 \mathrm{~min}$ in a reaction medium that consisted of $0.5 \mathrm{M} \mathrm{KCl}, 5 \mathrm{mM} \mathrm{CaCl}_{2}, 25 \mathrm{mM}$ Tris-maleate (pH 7.0), $6 \mathrm{mg} / \mathrm{mL} \mathrm{MP}$, and $1 \mathrm{mM}$ ATP. The reaction was terminated by adding $\mathrm{HClO}_{4}$ at $5 \%$ final concentration. The mixture was centrifuged at $9000 \mathrm{rpm}$ for $10 \mathrm{~min}$, and the released inorganic phosphate in the supernatant was measured by using phosphomolybdate method. The activity of $\mathrm{Ca}^{2+}$ ATPase of MP was expressed as Pi amount per $\mathrm{mg}$ of MP per reaction time liberation $\mathrm{min}^{-1}$ $(\mu \mathrm{mol} / \mathrm{mg} / \mathrm{min})^{-1}$.

\subsubsection{Surface Hydrophobicity}

Surface hydrophobicity of MP from the frozen surimi was characterized by using 8-anilino-1-naphthalenesulfonic acid (ANS) as the fluorescence probe according to Lin et al. with modifications [7]. The MP solution was diluted with $0.6 \mathrm{M} \mathrm{KCl}-10 \mathrm{mM}$ phosphate buffer ( $\mathrm{pH}$ 6.0) to achieve a series of protein concentrations of $0.2,0.3,0.5$ and $1.0 \mathrm{mg} / \mathrm{mL}$, 
and $20 \mu \mathrm{L}$ of $8 \mathrm{mM}$ ANS-0.1 M phosphate buffer ( $\mathrm{pH}$ 7.0) was added to $1 \mathrm{~mL}$ of the prepared protein solution. Fluorescence intensity (FI) of the mixture was measured immediately by using a fluorophotometer (F-4600, Hitiachi High Technologies Co., Tokyo, Japan) with excitation wavelength at $390 \mathrm{~nm}$ and emission wavelength at $420 \mathrm{~nm}$. The recorded FI vs. the concentration of MP $(\mathrm{mg} / \mathrm{mL})$ was plotted, and the initial slope was used as the index of protein surface hydrophobicity.

\subsubsection{Concentration of Sulfhydryl Group}

The concentration of sulfhydryl (-SH) group was determined via DTNB (5,5'-Dithiobis2-nitrobenzoic acid) assay as described by Jiang [32]. In brief, $1 \mathrm{~mL}$ of MP solution ( $4 \mathrm{mg} / \mathrm{mL})$ was mixed with $9 \mathrm{~mL}$ buffer A (8 mol/L urea, 2\% SDS and $10 \mathrm{mmol} / \mathrm{L}$ EDTA at $\mathrm{pH} 8.0)$, and $4 \mathrm{~mL}$ of the mixture was mixed with $0.5 \mathrm{~mL}$ buffer $\mathrm{B}(10 \mathrm{mM}$ DTNB and $0.2 \mathrm{M}$ Tris- $\mathrm{HCl}, \mathrm{pH} 8.0$ ). After incubation at $40^{\circ} \mathrm{C}$ for $25 \mathrm{~min}$, absorbance of the solution was determined at $412 \mathrm{~nm}$. The concentration of -SH group was calculated as Equation (1):

$$
x=\frac{\mathrm{A} \times \mathrm{D}}{\mathrm{C} \times \mathrm{B}}
$$

where $x$ represents the $\mathrm{SH}$ content $(\mathrm{mol} / \mathrm{g})$; $\mathrm{D}$ is the dilution factor; $\mathrm{A}$ is the absorbance of the mixture solution; $C$ is the molar extinction $\left(13,600 \mathrm{~mol}^{-1} \cdot \mathrm{cm}^{-1} \cdot \mathrm{L}\right)$; $\mathrm{B}$ is the protein concentration $(\mathrm{mg} / \mathrm{mL})$.

\subsubsection{Intrinsic Fluorescence Intensity}

Fluorescence intensity (FI) of MPs was measured with a fluorescence spectrophotometer (F-4600, Hitiachi High Technologies Co.) according to the method described by Walayat et al. [33]. Previously prepared MP solution (Section 2.3) was diluted to $0.05 \mathrm{mg} / \mathrm{mL}$ by using $0.6 \mathrm{M} \mathrm{NaCl}$ solution. The scan wavelength was in the range of 300 to $450 \mathrm{~nm}$, with the scanning speed at $1000 \mathrm{~nm} / \mathrm{min}$, and the excitation wavelength was $295 \mathrm{~nm}$ with both excitation and emission slits at $10 \mathrm{~nm}$.

\subsection{Preparation of Surimi Gels}

Surimi gel was prepared according to the method described by Tao et al. [8]. Frozen surimi was thawed at $4{ }^{\circ} \mathrm{C}$, chopped for $5 \mathrm{~min}$, mixed with $2.5 \% \mathrm{NaCl}$ addition followed by chopping for another $5 \mathrm{~min}$. The obtained surimi sol was then stuffed into a plastic polyvinylidene case and conditioned at $40{ }^{\circ} \mathrm{C}$ for $60 \mathrm{~min}$ followed by heating at $90{ }^{\circ} \mathrm{C}$ for $30 \mathrm{~min}$ (Figure S2). The obtained heat-set surimi gels were cooled in ice water for $30 \mathrm{~min}$ and stored at $4{ }^{\circ} \mathrm{C}$ overnight before further analysis.

\subsection{Characterizations of Surimi Gels}

\subsubsection{Scanning Electron Microscopy}

Scanning electron microscopy (SEM) was used to evaluate the microstructures of surimi gels. A cubic Surimi gel $\left(3 \times 3 \times 3 \mathrm{~mm}^{3}\right)$ was conditioned in $2 \%$ glutaraldehyde at $4{ }^{\circ} \mathrm{C}$ for $18 \mathrm{~h}$ and dehydrated with a series of concentrations of ethanol $(50,70,80,90$, and $100 \%$ ), followed by lyophilization. Then, gel samples were mounted on an aluminum stub, sputter coated with gold, and observed by SEM (Hitachi S-3500 N, Hitachi, Japan) at an accelerating voltage of $10 \mathrm{kV}$.

\subsubsection{Rheology Test}

Small amplitude oscillatory strain (SAOS) tests were performed with a Physica controlled stress rheometer (MCR-301, Anton Paar, Graz, Austria). A small piece of surimi gel was loaded between two parallel plates (20 mm diameter and $1 \mathrm{~mm}$ gap). Disk-shaped samples were mounted on the lower plate of the rheometer at $20.0 \pm 0.1^{\circ} \mathrm{C}$ and allowed to rest for $15 \mathrm{~min}$ before analyses. Then, a frequency sweep test $(0.1-100 \mathrm{~Hz})$ was carried out to evaluate the rheological variations of the gels prepared from surimi stored for different periods of time. The strain was fixed at $0.5 \%$ which was within the viscoelastic region 
(LVR), and the storage modulus $\left(\mathrm{G}^{\prime}\right)$ and loss modulus $\left(\mathrm{G}^{\prime \prime}\right)$ were recorded. Values of $\tan \delta$ were expressed as $G^{\prime \prime} / G^{\prime}$ at the testing frequency of $1 \mathrm{~Hz}$ and the temperature of $20{ }^{\circ} \mathrm{C}$.

\subsubsection{Gel Strength}

Gel strength was characterized on a TA. XT. plus Texture analyzer (SMS, Surrey, UK) according to the method of Liu et al. [14]. Surimi gels were cut into $25 \mathrm{~mm}$ high cylindrical shape slices. A slice was horizontally placed on the platform and penetrated by a spherical probe (type $\mathrm{P} / 0.25$ ). The testing speed of probe was $1 \mathrm{~mm} / \mathrm{s}$, the trigger point load was $0.1 \mathrm{~N}$, and the depth of probe penetration was $10 \mathrm{~mm}$. Gel strength $(\mathrm{g} / \mathrm{cm})$ was calculated by multiplying the breaking force $(\mathrm{g})$ by penetration distance $(\mathrm{mm})$.

\subsubsection{Water-Holding Capacity (WHC)}

WHC of surimi gels was measured according to the method described by Li et al. with minor modifications [4]. Surimi gels were cut into the thickness of $2.5 \mathrm{~mm}$ and centrifuged for $10 \mathrm{~min}$ at $1000 \mathrm{~g}$ and $4{ }^{\circ} \mathrm{C}$, and the released moisture was absorbed by filter paper. The weight of the gels was recorded before (W1) and after centrifugation (W2). WHC was calculated as Equation (2):

$$
\text { WHC }(\%)=(\mathrm{W} 1-\mathrm{W} 2) / \mathrm{W} 1 \times 100 \%
$$

\subsubsection{Whiteness}

The whiteness of surimi gel was determined with a colorimeter (CR-400, Konica Minolta, Osaka, Japan) by measuring L* (lightness), $a^{*}$ (redness/greenness) and b* (yellowness/blueness) values. Whiteness was calculated as Equation (3):

$$
\text { Whiteness } \left.\left.=100-100-L^{*}\right)^{2}+a^{* 2}+b^{* 2}\right]^{1 / 2}
$$

\subsubsection{Sensory Assessment of Surimi Gels}

Surimi gels (prepared in Section 2.5) were cut into square pieces $(1 \times 1 \times 2 \mathrm{~cm})$ for sensory assessment. The evaluation panelist was composed of 20 trained individuals, and the whole evaluation process was performed in a professional sensory evaluation laboratory at room temperature. A five-point hedonic score was recorded for each surimi gel, ranging from 5 (extremely like) to 1 (extremely dislike) in terms of the taste, smell, juiciness, color, texture and overall acceptability of the cooked surimi gel.

\subsection{Statistical Analysis}

All characterizations were repeated three times, and the reported results were shown as the mean \pm standard deviation. Significant difference among treatments was analyzed by using SPSS (Version 13.0 SPSS, Chicago, IL, USA) through analysis of variance (ANOVA) with Duncan's test. Statistical significance was accepted at $p<0.05$.

\section{Results and Discussions}

\subsection{Effect of CMCO on Storage Stability of MP}

\subsubsection{Salt-Soluble Protein Content}

$\mathrm{MP}$ is the dominant salt-soluble protein in the surimi, whose solubility variation is an important indicator to reflect its denaturation during frozen storage [34]. As shown in Figure $1 \mathrm{a}$, the salt solubility of MP from all groups of surimi were about $86 \mathrm{mg} / \mathrm{g}$ before freezing and kept decreasing during the entire storage period. After 60 days, the solubility of the control group reached $58 \mathrm{mg} / \mathrm{g}$. The decrease of protein solubility could be attributed to the freezing-induced denaturation/aggregation of MP in surimi as the storage time extended [12,35]. With the addition of cryoprotectants, the MP solubility of frozen surimi was significantly higher, whose values were 62,70 , and $72 \mathrm{mg} / \mathrm{g}$, respectively, regarding to $\mathrm{CMCO}-\mathrm{A}$, -B and commercial group. Similar to most other saccharide cryoprotectants, $\mathrm{CMCO}$ could restrain the movement of water molecules and inhibit the growth of ice 
in frozen surimi, which alleviated the MP denaturation. Moreover, the MP solubility of CMCO-B group was higher than that of CMCO-A at the same storage time. It has been shown that the complexity of hydrogen bonding enhanced in the food matrix as the DS of charged polysaccharide increased [20,36]; thus, water molecules became more bounded to the protein networks, which led to a better cryoprotective effect to the MP, i.e., CMCOB group > CMCO-A group, whose content of salt-soluble protein was 70 and $62 \mathrm{mg} / \mathrm{g}$, respectively.

(a)

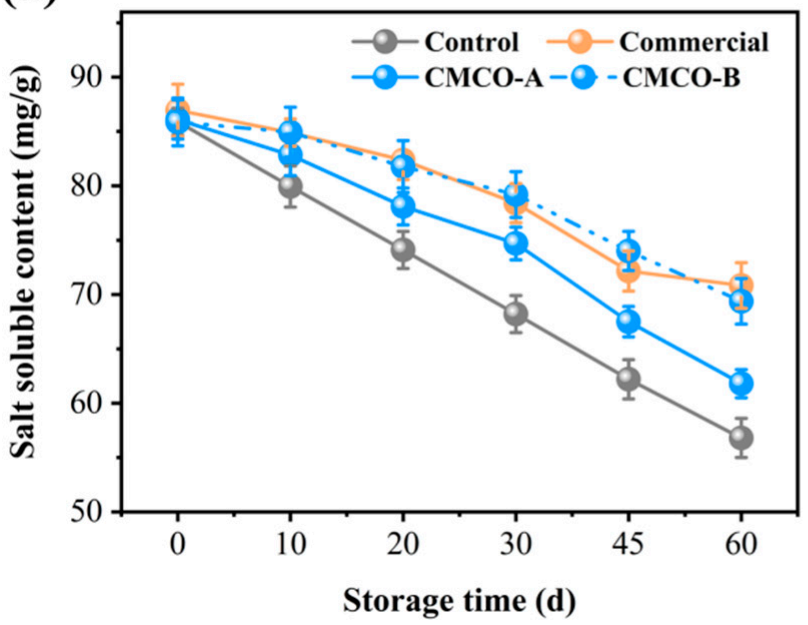

(b)

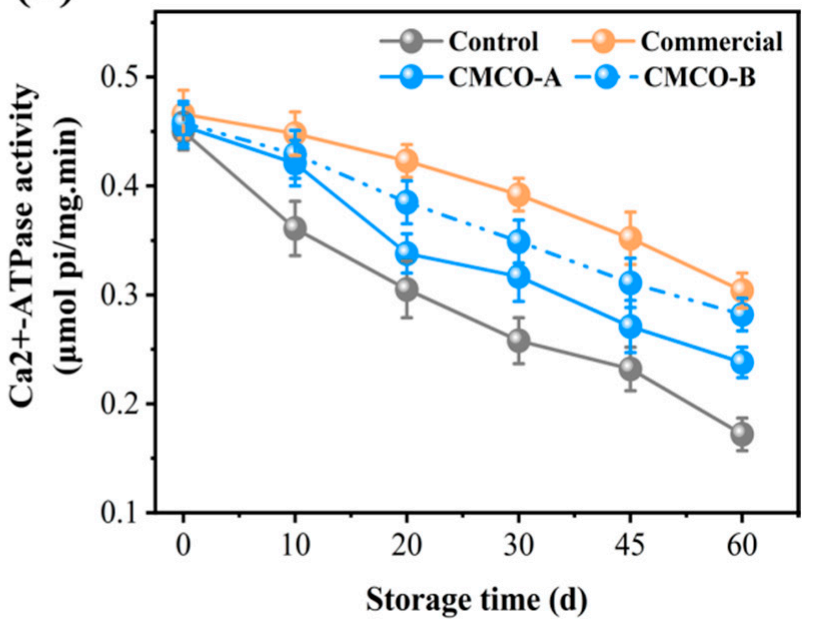

Figure 1. Effects of CMCO on salt-soluble protein content (a) and $\mathrm{Ca}^{2+}$-ATPase activity (b) of MP at different storage time.

\subsection{2. $\mathrm{Ca}^{2+}$-ATPase Activity}

$\mathrm{Ca}^{2+}$-ATPase activity is an important indicator to measure the structural integrity of MP in fish muscle [8]. The protein conformations can be changed along with the breakdown of intermolecular noncovalent bonding during storage, resulting in the decrease of $\mathrm{Ca}^{2+}$ ATPase activity [35]. Figure $1 \mathrm{~b}$ showed that the initial $\mathrm{Ca}^{2+}$-ATPase activity of MP of all frozen surimi samples were about at $0.45 \mu \mathrm{mol} \mathrm{pi} / \mathrm{mg} . \mathrm{min}$ before freezing and decreased to different degrees as storage time extended. The $\mathrm{Ca}^{2+}$-ATPase activity of the control group experienced the most significant decrease $(\sim 60 \%)$ to $0.17 \mu \mathrm{mol} \mathrm{pi} / \mathrm{mg} \cdot \mathrm{min}$ at day 60 . In consistent with the results of MP solubility (Section 3.1), the use of cryoprotectants (i.e., $\mathrm{CMCO}-\mathrm{A} / \mathrm{B}$ and the commercial additive) inhibited the protein denaturation. Specifically, the values of $\mathrm{Ca}^{2+}$-ATPase activity of the CMCO-A $(0.23 \mu \mathrm{mol} \mathrm{pi} / \mathrm{mg}$.min $)$ and $-\mathrm{B}(0.28 \mu \mathrm{mol}$ $\mathrm{pi} / \mathrm{mg}$.min $)$ were significantly higher than that of the control group $(0.17 \mu \mathrm{mol} \mathrm{pi} / \mathrm{mg} . \mathrm{min})$ at day 60 , even though they also decreased by $44.4 \%$ and $33.3 \%$, respectively, during storage. Meanwhile, the CMCO-B group achieved comparable 60-day $\mathrm{Ca}^{2+}$-ATPase activity (i.e., 0.28 vs. $0.30 \mu \mathrm{mol} \mathrm{pi} / \mathrm{mg}$.min) to the commercial group. A similar cryoprotective effect of pullulan was also reported by Jiang et al. [37].

\subsubsection{Surface Hydrophobicity and Sulfhydryl Content}

Variations of surface hydrophobicity reflect conformational changes of MP at different physical and chemical states. A reduced surface hydrophobicity suggests that the protein was less denatured (unfolded), and less hydrophobic groups were exposed, thus limiting the protein binding with the fluorescence probe [7]. As depicted in Figure 2a, surface hydrophobicity of the control group increased significantly from 3000 to 8800 after 60 days of storage. This phenomenon was reasonably due to the freezing-induced MP denaturation. Ice crystals that formed in surimi destroyed the hydration layer around the peptides, which resulted in more exposed hydrophobic amino acid residues and higher protein surface hydrophobicity [7]. In the presence of $\mathrm{CMCO}-\mathrm{A},-\mathrm{B}$ and commercial additive, the surface hydrophobicity of MP was lower than that of the control group, suggesting their 
cryoprotective effects on protein structures. $\mathrm{CMCO}$, an ampholytic saccharide with strong polarity, may interact with proteins and increase their hydrophilicities. Consequently, undesirable protein aggregation was inhibited as evidenced by the reduced hydrophobic interaction [38].

(a)

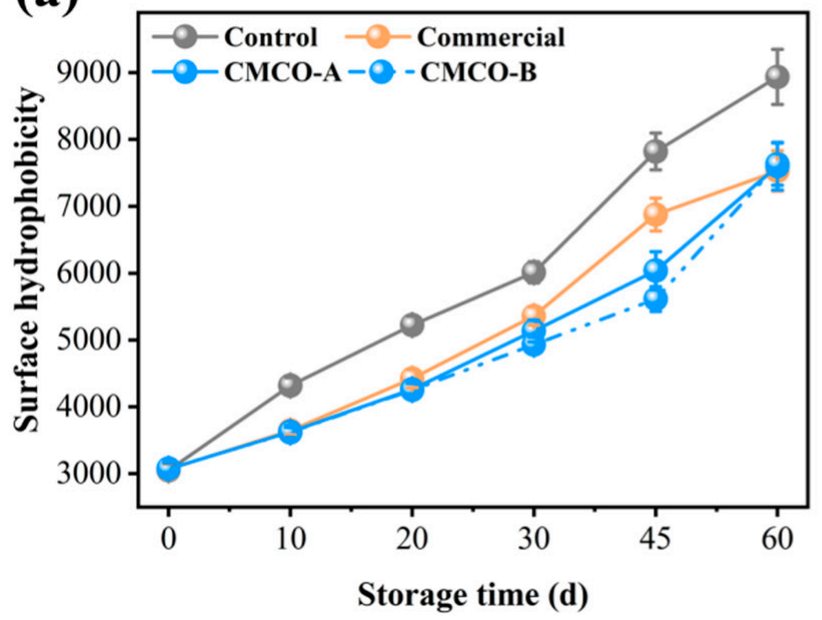

(b)

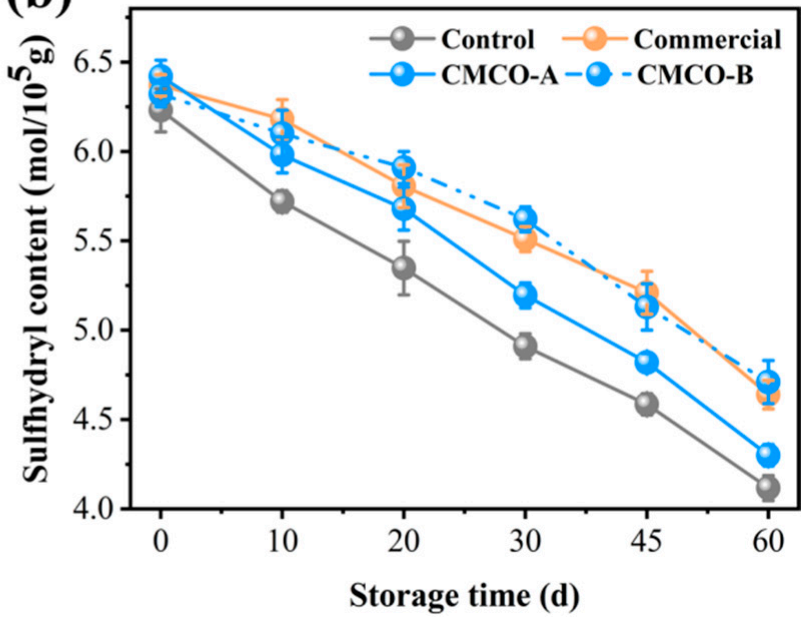

Figure 2. Effects of CMCO on surface hydrophobicity (a) and sulfhydryl content (b) of MP at different storage time.

To further elaborate the storage stability of MPs, the contents of their sulfhydryl groups were measured in the presence of different cryoprotectants (Figure 2b). During the 60 days of storage, the sulfhydryl content of the control group decreased significantly from 6.22 to $4.08 \mathrm{~mol} / 10^{5} \mathrm{~g}$, while the addition of CMCO-A and B mitigated such decrease with the final sulfhydryl contents of $4.31 \mathrm{~mol} / 10^{5} \mathrm{~g}$ and $4.73 \mathrm{~mol} / 10^{5} \mathrm{~g}$, respectively. Moreover, the CMCO-B group can achieve similar sulfhydryl contents of MP to the commercial group $\left(4.69 \mathrm{~mol} / 10^{5} \mathrm{~g}\right)$. The sulfhydryl group is chemically reactive. It could be easily oxidized to form disulfide bonds under long-term frozen storage [33], leading to serious protein aggregation, denaturation, and deterioration of food quality [39]. Owing to the strong reducing power of oligosaccharide, $\mathrm{CMCO}$ could inhibit the oxidation and conversion of SH to disulfide bond, thus maintaining the storage stability of MP [14].

\subsubsection{Intrinsic Fluorescence Intensity}

The intrinsic fluorescence intensity (FI) of MP in frozen surimi was characterized by using fluorescence spectroscopy. It reflected the changes of chemical environment of tryptophan (Trp) residues, which suggested the variation of protein tertiary structures [40]. As shown in Figure 3, the FI of all MP samples was similar at Day 0, and decreased as far as the storage period elapsed, indicating the exposure of Trp residue towards solvent [41]. These results agreed with findings about the structural integrity of MP molecules $\left(\mathrm{Ca}^{2+}\right.$ ATPase activity in Figure 1b), which also experienced significant decreases as the tertiary structure of MP became collapsed during long-term frozen storage [41]. In the presence of different cryoprotectants, reduction of FI became less obvious compared to the control group, and relatively higher FI was observed for the CMCO-B group than the CMCO-A during the entire storage period. A similar charge-dependent cryoprotective behavior of ampholetic saccharides was also observed in our recent study [20], in which CMCh could stabilize the microstructures of wheat gluten in frozen dough, and the protective effect was more obvious as DS of CMCh increased. 

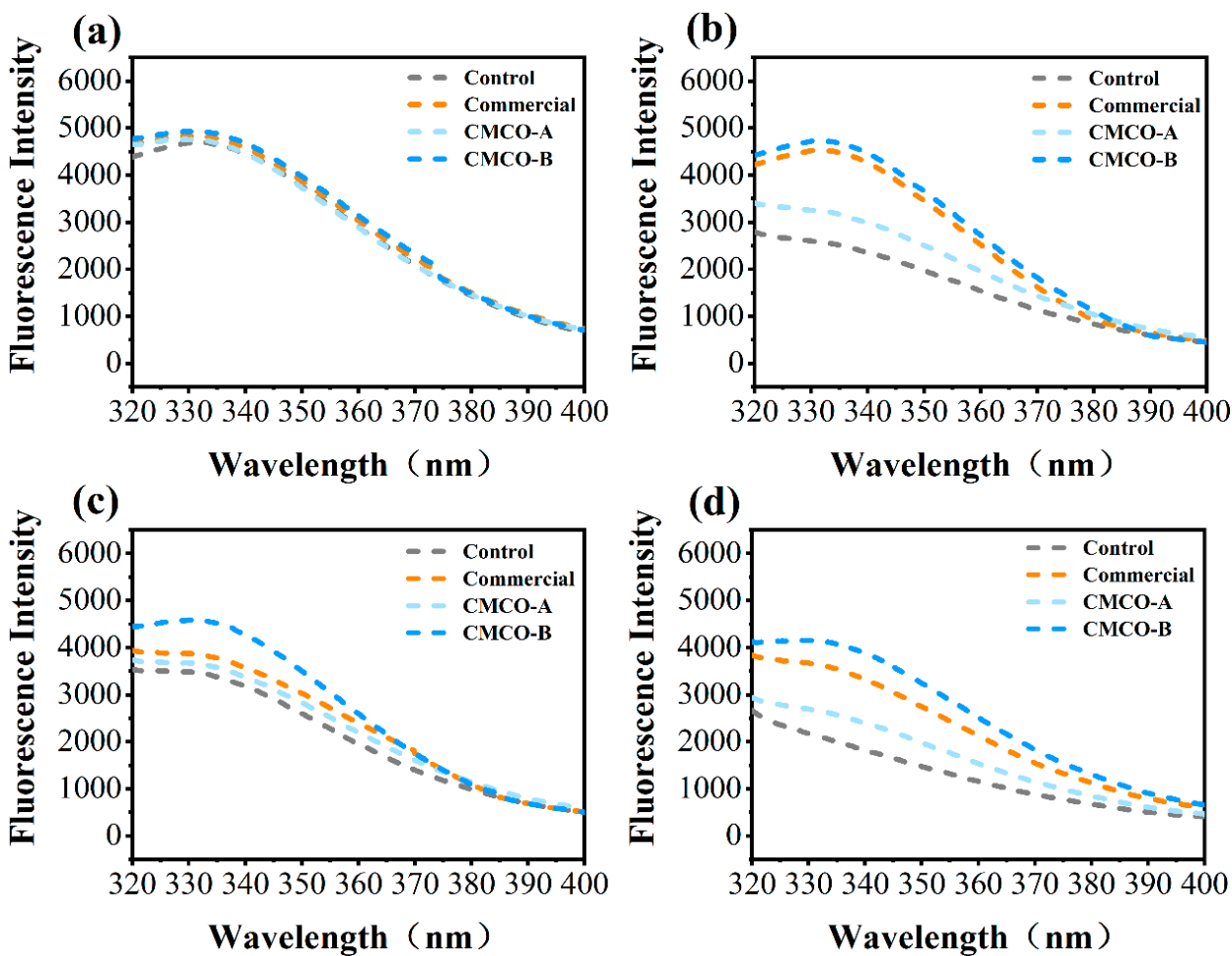

Figure 3. Effects of $\mathrm{CMCO}$ on fluorescence intensity of MP at different storage time: (a) day 0 , (b) day 15, (c) day 30, and (d) day 60.

\subsection{Effect of CMCO on Gel Behaviors of Frozen Surimi}

3.2.1. Effect of $\mathrm{CMCO}$ on the Microstructure of Gels Prepared from Frozen Surimi

A porous protein network is formed during the two-stage thermal processing of surimi, which determines many important quality attributes of the gel products, such as texture, shelf life and digestion etc. $[42,43]$. Therefore, SEM was applied to observe the microstructure of gels prepared from frozen surimi. As shown in Figure 4, all gel samples of fresh surimi exhibited reticular and continuous protein network. After frozen storage, the gel matrix became loose for the control group, seen from the increase of heterogenic pore sizes. In contrast, the addition of cryoprotectants alleviated the breakdown of honeycomblike network of surimi gels, which were beneficial to the mechanical strength of gel matrix. Besides, a more continuous and ordered protein architecture was observed for surimi gel of the CMCO-B group than that of the CMCO-A. A similar phenomenon was also reported by Tan et al. [13], who investigated the gel morphology of frozen surimi treated by cellulosic oligosaccharide.
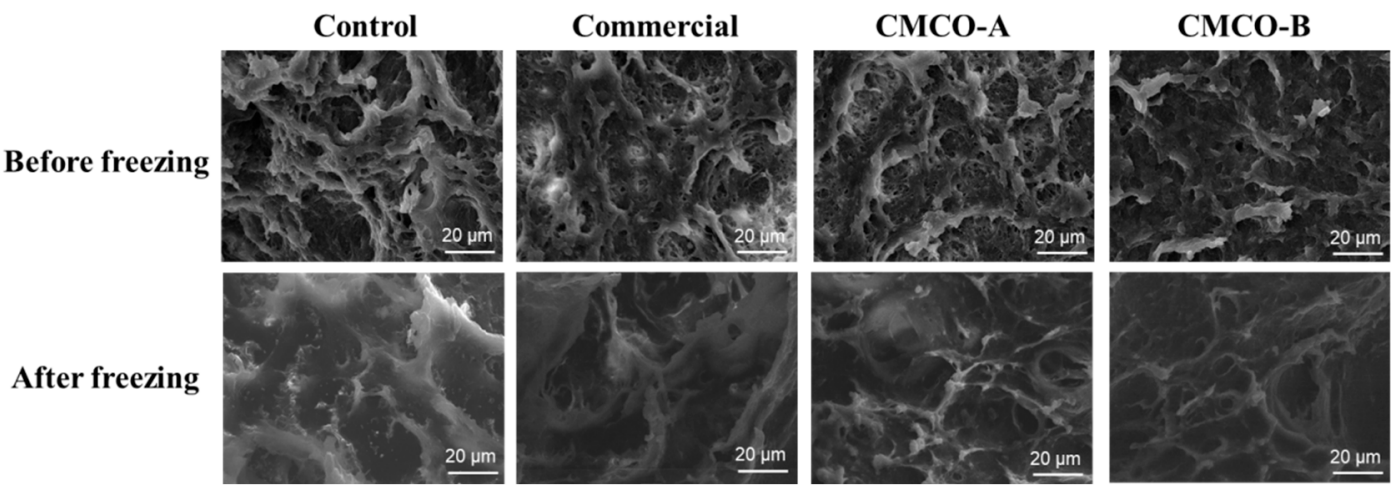

Figure 4. Microstructure of the gels prepared from frozen surimi with different cryoprotectants before and after storage for 60 days. 


\subsubsection{Effect of $\mathrm{CMCO}$ on the Rheological Properties of Surimi Gels}

The rheological properties of surimi gels also changed significantly as the MP became denatured during frozen storage. As shown in Figure $5 a, b$, the elastic moduli $\left(G^{\prime}\right)$ of all surimi gels were higher than those of the viscous moduli $\left(G^{\prime \prime}\right)$ at both day 0 and day 60 , indicating their solidlike behaviors. To better illustrate the gel characteristics, loss tangents $(\tan \delta)$ of surimi gels during frequency sweep were recorded (Figure $5 \mathrm{c}$ ). The reduced elasticities were observed for all groups of surimi gels, as evidenced by their ever-increased $\tan \delta$ (i.e., less elastic) after freezing storage. These results were correlated with the formed heterogeneous gel networks prepared from the stored surimi (Figure 4). In the cases of cryoprotected surimi, their gel structures were maintained, thus exhibiting lower $\tan \delta$ compared to the control. After 60 days, the lowest $\tan \delta$ was obtained for the CMCO-B group at 0.16 . These observations were in consistent with the effect of antifreeze proteins on rheological properties of the frozen surimi $[33,42]$.

(a)

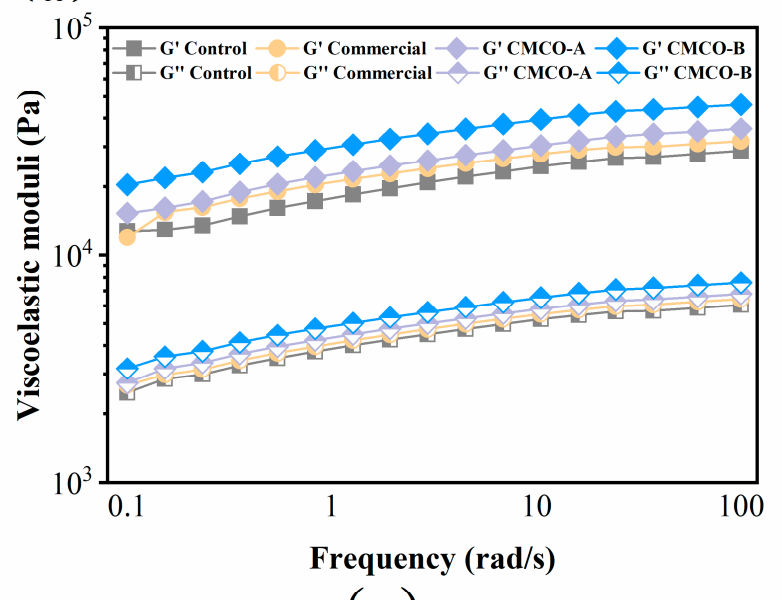

(b)

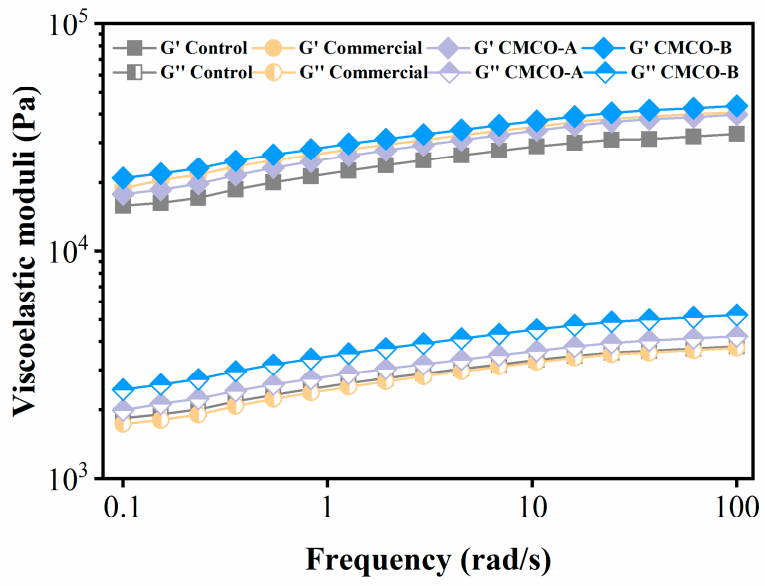

(c)

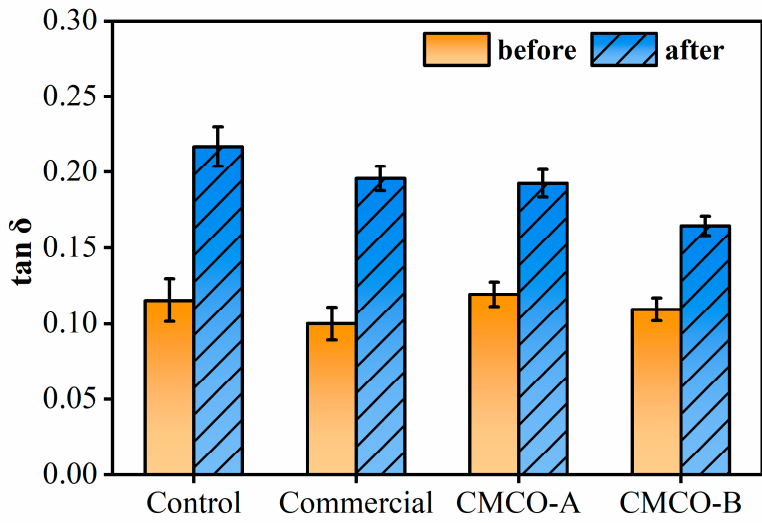

Figure 5. Dynamic rheological properties of the gels prepared from frozen surimi before (a) and after (b) frozen storage, and (c) tan $\delta$ of surimi gel within the linear viscoelastic region. Values with different uppercase letters indicate statistically significant difference among samples with different cryoprotectants at the same storage time $(p<0.05)$. Values with different lowercase letters indicate significant difference among samples with the same cryoprotectants at different storage time $(p<0.05)$.

\subsubsection{Effect of CMCO on the Gel Strength and Water-Holding Capacity}

Gel weakening is one of the most typical quality deteriorations for surimi products, which occurs during the whole process of cold chain transportation, storage and communications $[44,45]$. Thus, the gel strengths of frozen surimi with different cryoprotectants were characterized (Figure 6a). Few significant differences were observed among the samples at 
day 0 , and the weakening effect was observed as storage time prolonged. After 60 days, gel strength of the control group exhibited the most significant decrease from 288 to $158 \mathrm{~g} \cdot \mathrm{cm}$. The weakening effect was suppressed in the presence of cryoprotectants, and the highest gel strength of $219 \mathrm{~g} \cdot \mathrm{cm}$ was obtained for the CMCO-B group. As previously discussed (Section 3.1), introduction of CMCO to frozen surimi may preserve the MP integrity (solubility, $\mathrm{Ca}^{2+}$-ATPase, sulphydryl, and intrinsic FI), which stabilized protein networks and enhanced mechanical strengths of surimi gels.

In addition to the gel strength, WHC is another important parameter to evaluate edible qualities of gel-type foods. As shown in Figure 6b, WHC of all surimi gels kept decreasing during storage, which could be owing to the muscle filament contraction and protein denaturation/ tertiary structural changes [5]. In the presence of different cryoprotectants, such reduction of WHC became less obvious. After 60 days, the CMCO-A, CMCO-B, and commercial groups exhibited significantly higher $\mathrm{WHC}(79.20 \%, 85.70 \%$, and 86.50\%, respectively) than the control group $(68.50 \%)$. The improved WHC may be due to the cryoprotective effect of CMCO to the gel structures. The intrinsic ampholytic characteristics of CMCO may endow the saccharide superior hydrophilicity, which helped reduce the ice crystallization, improve the gelling property and finally enhance the WHC [12]. In consistent with the results of mechanical strength, as the DS of CMCO increased, the WHC of surimi gels were enhanced ( $\mathrm{CMCO}-\mathrm{B}>\mathrm{CMCO}-\mathrm{A})$.

(a)

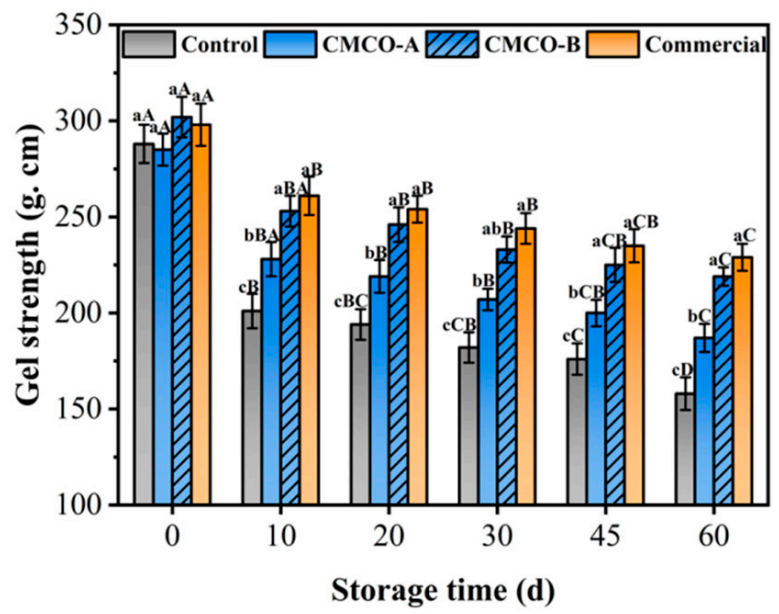

(b)

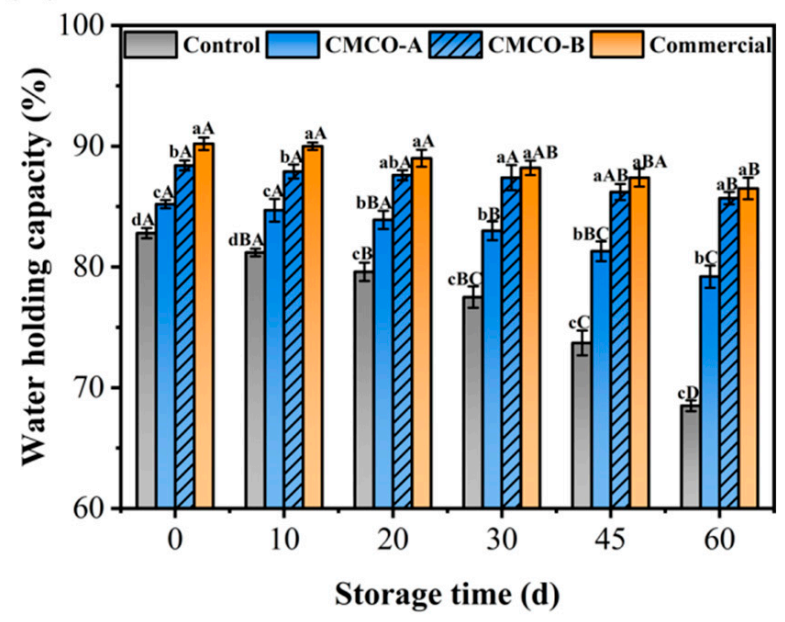

Figure 6. Effects of CMCO on the mechanical strength (a) and water-holding capacity (b) of the gels prepared from frozen surimi at different storage time. Values with different uppercase letters indicate statistically significant difference among samples with different cryoprotectants at the same storage time $(p<0.05)$. Values with different lowercase letters indicate significant difference among samples with the same cryoprotectants at different storage time $(p<0.05)$.

Collectively, the cryoprotective mechanism of CMCO can be described from molecular perspective (Figure 7). CMCO could interact with MP through both hydrogen bonding and electrostatic complexation, which replaces the water molecules at MP surface, and prevents the freezing-induced protein aggregation [41,42]. In addition, the ampholytic structure of oligosaccharide could entrap the water, modulate the growth of ice crystals, and stabilize MP structures [46]. Thus, after thermal processing, the gel of cryoprotected surimi exhibited more organized microstructures and improved mechanical properties. It is also noteworthy that the inhibitory effect of saccharide to ice crystallization may also account for the cryoprotective behaviors of CMCO to frozen surimi [47-49], and in most cases, both the protein-stabilization and ice-inhibition effects worked concurrently. 


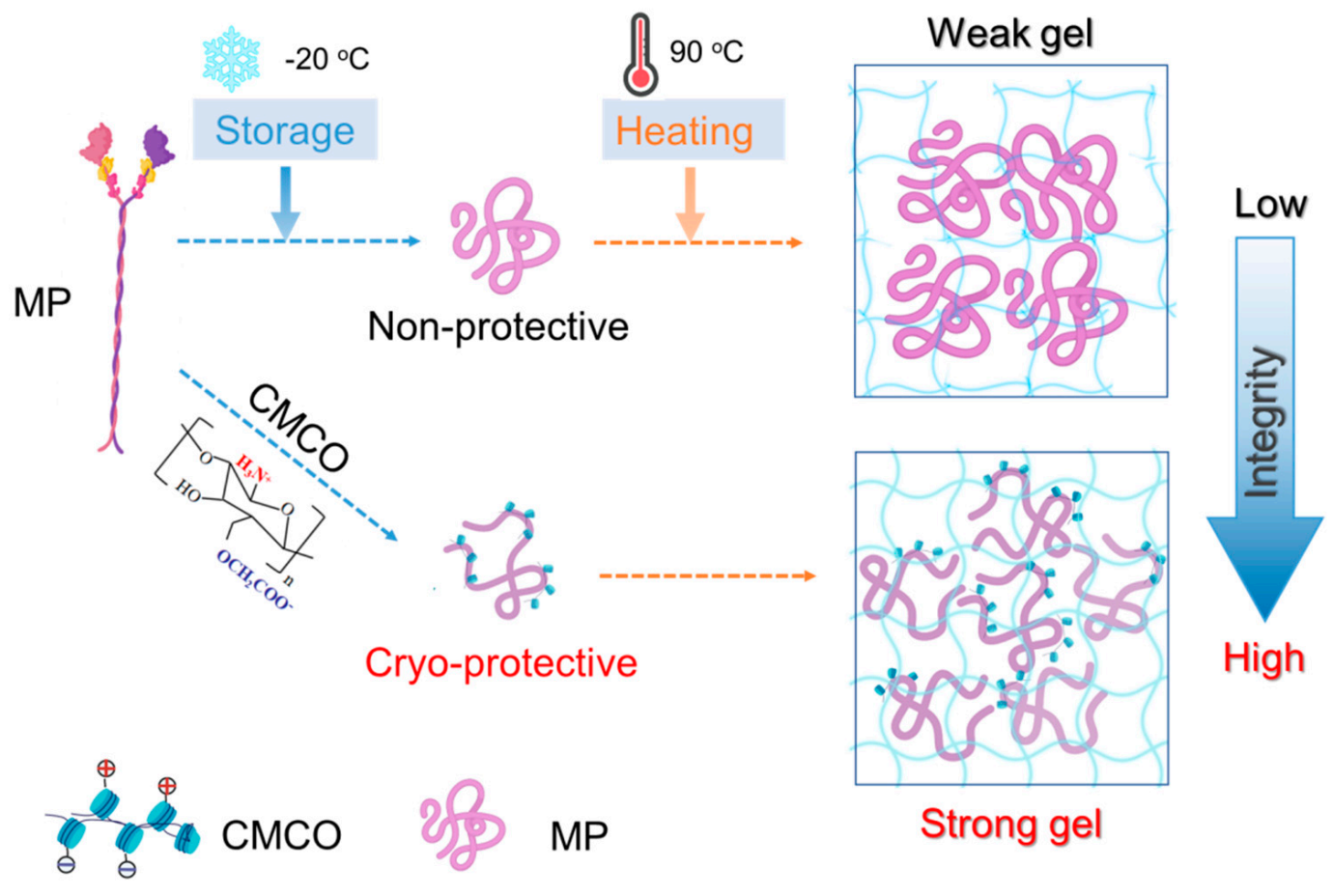

Figure 7. Schematic representation of the cryoprotective mechanism of CMCO for MP in frozen surimi.

\subsection{Effect of CMCO on the Whiteness and Sensory Quality of Frozen Surimi}

Decreased whiteness of gel products made from frozen surimi is a common problem impairing their appearance and edible qualities. As depicted in Figure 8, the whiteness value of the control group kept decreasing from 0 to 60 days. As expected, the addition of cryoprotectants could limit the loss of whiteness of surimi gels, whose values of CMCO-A, $-\mathrm{B}$, and commercial group experienced no significant difference during the entire storage period. Similar phenomenon was also reported by Tao and Walayat $[5,8]$ who attributed the decline of gel whiteness to the combined effects of nonenzymatic protein oxidation and crystallization-induced protein denaturation. The addition of oligosaccharides could prevent those protein deteriorations and thus maintain the whiteness of gels prepared from frozen surimi [50].

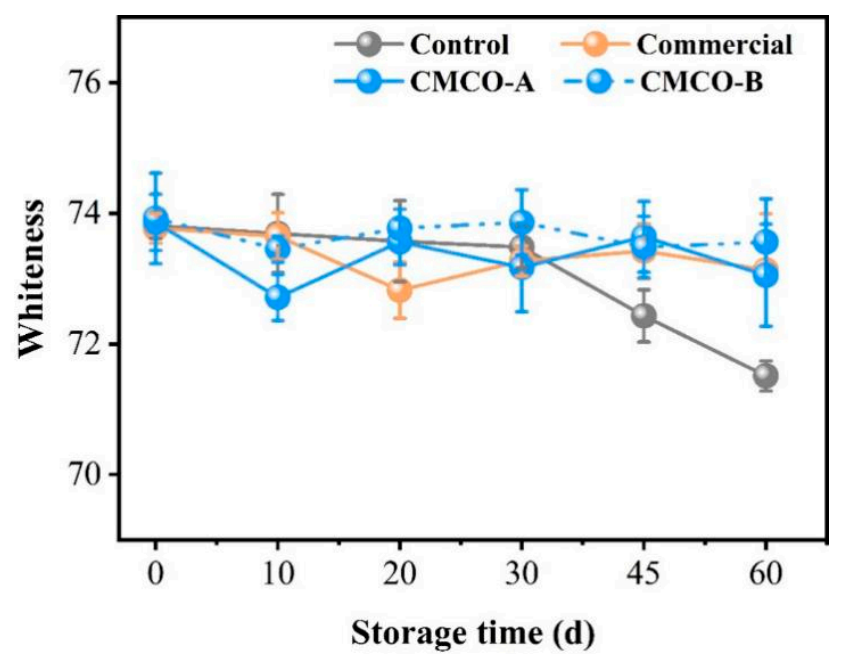

Figure 8. Effects of the $\mathrm{CMCO}$ on whiteness of the gels prepared from frozen surimi at different storage time. 
Sensory evaluations of all surimi gels were performed by panelists (Table 1). The average sensory scores of surimi gels enhanced in terms of flavor, taste, juiciness, texture, and color through the addition of cryoprotectants. Moreover, gels of the CMCO-B group exhibited slightly higher overall acceptability than that of the CMCO-A and commercial group. In agreement with the results of gel strength, and whiteness (Figure 6), the CMCO-B could act as a high-performance cryoprotectant to improve the edible quality of the frozen stored surimi.

Table 1. Effect of CMCO on sensory attributes of the gels prepared from frozen surimi after 60 days of storage.

\begin{tabular}{ccccc}
\hline & Control & CMCO-A & CMCO-B & Commercial \\
\hline Taste & $3.78 \pm 0.43^{\mathrm{b}}$ & $4.18 \pm 0.31^{\mathrm{a}}$ & $4.34 \pm 0.35^{\mathrm{a}}$ & $4.22 \pm 0.27^{\mathrm{ab}}$ \\
Smell & $4.09 \pm 0.45^{\mathrm{a}}$ & $4.38 \pm 0.35^{\mathrm{a}}$ & $4.51 \pm 0.38^{\mathrm{a}}$ & $4.46 \pm 0.40^{\mathrm{a}}$ \\
Texture & $3.60 \pm 0.25^{\mathrm{b}}$ & $3.93 \pm 0.34^{\mathrm{ab}}$ & $4.17 \pm 0.27^{\mathrm{a}}$ & $4.20 \pm 0.32^{\mathrm{a}}$ \\
Juiciness & $3.52 \pm 0.28^{\mathrm{b}}$ & $4.38 \pm 0.31^{\mathrm{a}}$ & $4.51 \pm 0.35^{\mathrm{a}}$ & $4.46 \pm 0.30^{\mathrm{a}}$ \\
Color & $4.08 \pm 0.24^{\mathrm{a}}$ & $4.12 \pm 0.22^{\mathrm{a}}$ & $4.10 \pm 0.25^{\mathrm{a}}$ & $4.15 \pm 0.33^{\mathrm{a}}$ \\
Overall acceptability & $3.93 \pm 0.35^{\mathrm{b}}$ & $4.38 \pm 0.27^{\mathrm{ab}}$ & $4.67 \pm 0.34^{\mathrm{a}}$ & $4.49 \pm 0.31^{\mathrm{a}}$
\end{tabular}

Different letters indicate statistically significant differences among samples with different cryoprotectants $(p<0.05)$

\section{Conclusions}

The present study designated the cryoprotective effects of ampholetic oligosaccharide (CMCO) on the storage stability of frozen surimi. An addition of $0.6 \%(w / w) \mathrm{CMCO}$ can alleviate the denaturation of MP in the frozen surimi during 60 days of storage at $-18{ }^{\circ} \mathrm{C}$ as indicated by their increased salt-protein solubility, $\mathrm{Ca}^{2+}$-ATPase activity, and sulfhydryl content. The CMCO-protected MP experienced less conformation changes (reflected by the surface hydrophobicity and FI) than the nonprotected control. Accordingly, the obtained surimi gels demonstrated significantly improved elasticity, mechanical strength, and WHC, and had more uniform microstructure upon thermal processing. Moreover, the cryoprotective effect of CMCO-B (DS: 1.2) was more pronounced than that of CMCO-A (DS of 0.8). The gel strength and WHC of the CMCO-B group were comparable to those of the commercial counterpart (4\% sucrose and $4 \%$ sorbitol). Results of sensory evaluation showed that CMCO addition also improved the taste, smell, texture, juiciness, whiteness, and overall acceptability of gels prepared from frozen surimi. Findings from this study deepen the scientific insights of ampholytic saccharides as high-performance cryoprotectants in food industry.

Supplementary Materials: The following supporting information can be downloaded at: https: / / www.mdpi.com/article/10.3390/foods11030356/s1, Figure S1: The chemical structure of carboxymethyl chitosan; Figure S2: A schematic demonstration to the processing of surimi.

Author Contributions: Conceptualization, X.Z. and M.Z.; methodology, M.Z., X.L. and D.H.; validation, L.W., T.Y. and Y.Z.; investigation, X.Z., X.L., L.S. and M.Z.; resources, T.Y. and L.S.; data curation, D.H., X.Z. and M.Z.; writing—original draft preparation, X.Z., D.H. and X.L. writingreview and editing, X.Z., T.Y., Y.Z. and J.X.; visualization, X.L. and M.Z.; project administration, X.Z. and T.Y.; funding acquisition: X.Z. All authors have read and agreed to the published version of the manuscript.

Funding: This research was funded by National Natural Science Foundation of China (31871870), Hubei Provincial Natural Science Foundation of China (Grant No. 2021CFB283) and Hubei University of Technology (BSQD-2020037, XBTK-2020001).

Institutional Review Board Statement: Not applicable.

Informed Consent Statement: Not applicable.

Data Availability Statement: Not applicable. 


\begin{abstract}
Acknowledgments: This work is financially supported by National Natural Science Foundation of China (31871870), Hubei Provincial Natural Science Foundation of China (Grant No. 2021CFB283), Doctoral start-up fund (BSQD-2020037) and Collaborative Grant-in-Aid of HBUT National "111" center for cellular Regulation and Molecular Pharmaceutics (XBTK-2020001) of Hubei University of Technology. The authors would like to thank Yunyun Zou from the shiyanjia lab (www.shiyanjia.com) for the fluorescence test.
\end{abstract}

Conflicts of Interest: The authors declare no conflict of interest.

\title{
References
}

1. Okita, A.; Takahashi, K.; Itakura, M.; Horio, A.; Yamamoto, R.; Nakamura, Y.; Osako, K. A novel soft surimi gel with functionality prepared using alcalase for people suffering from dysphagia. Food Chem. 2020, 344, 128641. [CrossRef]

2. Borderías, A.J.; Tovar, C.A.; Domínguez-Timón, F.; Díaz, M.T.; Pedrosa, M.M.; Moreno, H.M. Characterization of healthier mixed surimi gels obtained through partial substitution of myofibrillar proteins by pea protein isolates. Food Hydrocoll. 2020, $107,105976$. [CrossRef]

3. Dara, P.K.; Geetha, A.; Mohanty, U.; Raghavankutty, M.; Mathew, S.; Chandragiri Nagarajarao, R.; Rangasamy, A. Extraction and Characterization of Myofibrillar Proteins from Different Meat Sources: A Comparative Study. J. Bioresour. Bioprod. 2021, 6, 367-378. [CrossRef]

4. $\quad$ Li, J.; Munir, S.; Yu, X.; Yin, T.; You, J.; Liu, R.; Xiong, S.; Hu, Y. Double-crosslinked effect of TGase and EGCG on myofibrillar proteins gel based on physicochemical properties and molecular docking. Food Chem. 2021, 345, 128655. [CrossRef]

5. Walayat, N.; Xiong, Z.; Xiong, H.; Moreno, H.M.; Li, Q.; Nawaz, A.; Zhang, Z.; Wang, P.; Niaz, N. The effectiveness of egg white protein and $\beta$-cyclodextrin during frozen storage: Functional, rheological and structural changes in the myofibrillar proteins of Culter alburnus. Food Hydrocoll. 2020, 105, 105842. [CrossRef]

6. Singh, A.; Benjakul, S.; Prodpran, T.; Nuthong, P. Effect of Psyllium (Plantago ovata Forks) Husk on Characteristics, Rheological and Textural Properties of Threadfin Bream Surimi Gel. Foods 2021, 10, 1181. [CrossRef]

7. Lin, J.; Hong, H.; Zhang, L.; Zhang, C.; Luo, Y. Antioxidant and cryoprotective effects of hydrolysate from gill protein of bighead carp (Hypophthalmichthys nobilis) in preventing denaturation of frozen surimi. Food Chem. 2019, 298, 124868. [CrossRef]

8. Tao, L.; Tian, L.; Zhang, X.; Huang, X.; Long, H.; Chang, F.; Li, T.; Li, S. Effects of $\gamma$-polyglutamic acid on the physicochemical properties and microstructure of grass carp (Ctenopharyngodon idellus) surimi during frozen storage. LWT 2020, 134, 109960. [CrossRef]

9. Bao, Y.; Ertbjerg, P.; Estévez, M.; Yuan, L.; Gao, R. Freezing of meat and aquatic food: Underlying mechanisms and implications on protein oxidation. Compr. Rev. Food Sci. Food Saf. 2021, 20, 5548-5569. [CrossRef]

10. Tian, Y.; Zhu, Z.; Sun, D.W. Naturally sourced biosubstances for regulating freezing points in food researches: Fundamentals, current applications and future trends. Trends Food Sci. Technol. 2020, 95, 131-140. [CrossRef]

11. Huang, J.; Bakry, A.M.; Zeng, S.; Xiong, S.; Yin, T.; You, J.; Fan, M.; Huang, Q. Effect of phosphates on gelling characteristics and water mobility of myofibrillar protein from grass carp (Ctenopharyngodon idellus). Food Chem. 2019, 272, 84-92. [CrossRef]

12. Walayat, N.; Wang, X.; Liu, J.; Nawaz, A.; Zhang, Z.; Khalifa, I.; Rincón Cervera, M.Á.; Pateiro, M.; Lorenzo, J.M.; Nikoo, M.; et al. Kappa-carrageenan as an effective cryoprotectant on water mobility and functional properties of grass carp myofibrillar protein gel during frozen storage. LWT 2022, 154, 112675. [CrossRef]

13. Tan, M.; Ding, Z.; Mei, J.; Xie, J. Effect of cellobiose on the myofibrillar protein denaturation induced by pH changes during freeze-thaw cycles. Food Chem. 2021, 131511. [CrossRef]

14. Liu, J.; Fang, C.; Luo, Y.; Ding, Y.; Liu, S. Effects of konjac oligo-glucomannan on the physicochemical properties of frozen surimi from red gurnard (Aspitrigla cuculus). Food Hydrocoll. 2019, 89, 668-673. [CrossRef]

15. Yosri, N.; Khalifa, S.A.M.; Guo, Z.; Xu, B.; Zou, X.; El-Seedi, H.R. Marine organisms: Pioneer natural sources of polysaccharides/proteins for green synthesis of nanoparticles and their potential applications. Int. J. Biol. Macromol. 2021, 193, 1767-1798. [CrossRef]

16. Tian, J.; Walayat, N.; Ding, Y.; Liu, J. The role of trifunctional cryoprotectants in the frozen storage of aquatic foods: Recent developments and future recommendations. Compr. Rev. Food Sci. Food Saf. 2021, 321-339. [CrossRef]

17. Zhu, S.; Yu, J.; Chen, X.; Zhang, Q.; Cai, X.; Ding, Y.; Zhou, X.; Wang, S. Dual cryoprotective strategies for ice-binding and stabilizing of frozen seafood: A review. Trends Food Sci. Technol. 2021, 111, 223-232. [CrossRef]

18. Zhang, B.; Qi, X.E.; Mao, J.L.; Ying, X.G. Trehalose and alginate oligosaccharides affect the stability of myosin in whiteleg shrimp (Litopenaeus vannamei): The water-replacement mechanism confirmed by molecular dynamic simulation. LWT 2020, 127, 109393. [CrossRef]

19. Zhang, B.; Cao, H.J.; Lin, H.M.; Deng, S.G.; Wu, H. Insights into ice-growth inhibition by trehalose and alginate oligosaccharides in peeled Pacific white shrimp (Litopenaeus vannamei) during frozen storage. Food Chem. 2019, 278, 482-490. [CrossRef]

20. Zhu, X.; Yuan, P.; Zhang, T.; Wang, Z.; Cai, D.; Chen, X.; Shen, Y.; Xu, J.; Song, C.; Goff, D. Effect of carboxymethyl chitosan on the storage stability of frozen dough: State of water, protein structures and quality attributes. Food Res. Int. 2022, 151, 110863. [CrossRef] 
21. Zhu, X.; Chen, J.; Hu, Y.; Zhang, N.; Fu, Y.; Chen, X. Tuning complexation of carboxymethyl cellulose/ cationic chitosan to stabilize Pickering emulsion for curcumin encapsulation. Food Hydrocoll. 2021, 110, 106135. [CrossRef]

22. Shariatinia, Z. Carboxymethyl chitosan: Properties and biomedical applications. Int. J. Biol. Macromol. 2018, 120, 1406-1419. [CrossRef]

23. Wang, H.; Gong, X.; Miao, Y.; Guo, X.; Liu, C.; Fan, Y.Y.; Zhang, J.; Niu, B.; Li, W. Preparation and characterization of multilayer films composed of chitosan, sodium alginate and carboxymethyl chitosan-ZnO nanoparticles. Food Chem. 2019, 283, 397-403. [CrossRef]

24. Liu, X.; Zhi, X.; Liu, Y.; Wu, B.; Sun, Z.; Shen, J. Effect of chitosan, O-carboxymethyl chitosan, and N-[(2-hydroxy-3-N, Ndimethylhexadecyl ammonium)propyl] chitosan chloride on overweight and insulin resistance in a murine diet-induced obesity. J. Agric. Food Chem. 2012, 60, 3471-3476. [CrossRef]

25. He, Y.; Wu, X.; Zhang, G.; Huang, X.; Zhang, W.; Tu, M.; Zeng, R. A zwitterionic serine modified chitosan derivative for improving protein stability and activity. Int. J. Biol. Macromol. 2020, 163, 1738-1746. [CrossRef]

26. Inanli, A.G.; Tümerkan, E.T.A.; El Abed, N.; Regenstein, J.M.; Özogul, F. The impact of chitosan on seafood quality and human health: A review. Trends Food Sci. Technol. 2020, 97, 404-416. [CrossRef]

27. Chen, J.; Deng, T.; Wang, C.; Mi, H.; Yi, S.; Li, X.; Li, J. Effect of hydrocolloids on gel properties and protein secondary structure of silver carp surimi. J. Sci. Food Agric. 2020, 100, 2252-2260. [CrossRef]

28. Ge, H.; Luo, D. Preparation of carboxymethyl chitosan in aqueous solution under microwave irradiation. Carbohydr. Res. 2005, 340, 1351-1356. [CrossRef]

29. Chang, C.; Lin, Y.; Lu, S.; Huang, C.; Wang, Y.; Chung, Y. Characterization of a Chitosanase from Jelly Fig (Ficus awkeotsang Makino) Latex and Its Application in the Production of Water-Soluble Low Molecular Weight Chitosans. PLoS ONE 2016, 11, e0150490. [CrossRef]

30. Wang, H.B.; Pan, S.K.; Wu, S.J. Chitooligosaccharides suppress the freeze-denaturation of actomyosin in Aristichthys nobilis surimi protein. Int. J. Biol. Macromol. 2014, 63, 104-106. [CrossRef]

31. Zhang, L.; Li, Q.; Hong, H.; Luo, Y. Prevention of protein oxidation and enhancement of gel properties of silver carp (Hypophthalmichthys molitrix) surimi by addition of protein hydrolysates derived from surimi processing by-products. Food Chem. $\mathbf{2 0 2 0}$ 316, 126343. [CrossRef]

32. Jiang, X.; Chen, Q.; Xiao, N.; Du, Y.; Feng, Q.; Shi, W. Changes in Gel Structure and Chemical Interactions of Hypophthalmichthys molitrix Surimi Gels: Effect of Setting Process and Different Starch Addition. Foods 2021, 11, 9. [CrossRef]

33. Walayat, N.; Xiong, Z.; Xiong, H.; Moreno, H.M.; Niaz, N.; Ahmad, M.N.; Hassan, A.; Nawaz, A.; Ahmad, I.; Wang, P.K. Cryoprotective effect of egg white proteins and xylooligosaccharides mixture on oxidative and structural changes in myofibrillar proteins of Culter alburnus during frozen storage. Int. J. Biol. Macromol. 2020, 158, 865-874. [CrossRef]

34. Nikoo, M.; Benjakul, S.; Ahmadi Gavlighi, H.; Xu, X.; Regenstein, J.M. Hydrolysates from rainbow trout (Oncorhynchus mykiss) processing by-products: Properties when added to fish mince with different freeze-thaw cycles. Food Biosci. 2019, $30,100418$. [CrossRef]

35. Coombs, C.; Holman, B.; Collins, D.; Kerr, M.; Friend, M.; Hopkins, D. Effects of chilled-then-frozen storage (up to 52 weeks) on an indicator of protein oxidation and indices of protein degradation in lamb M. longissimus lumborum. Meat Sci. 2018, 135, 134-141. [CrossRef]

36. Ke, Y.; Wang, Y.; Ding, W.; Leng, Y.; Lv, Q.; Yang, H.; Wang, X.; Ding, B. Effects of inulin on protein in frozen dough during frozen storage. Food Funct. 2020, 11, 7775-7783. [CrossRef]

37. Jiang, L.; Wu, S. Pullulan suppresses the denaturation of myofibrillar protein of grass carp (Ctenopharyngodon idella) during frozen storage. Int. J. Biol. Macromol. 2018, 112, 1171-1174. [CrossRef]

38. Karnjanapratum, S.; Benjakul, S. Cryoprotective and antioxidative effects of gelatin hydrolysate from unicorn leatherjacket skin. Int. J. Refrig. 2015, 49, 69-78. [CrossRef]

39. Nawaz, A.; Xiong, Z.; Xiong, H.; Irshad, S.; Chen, L.; Wang, P.K.; Ahsan, H.M.; Walayat, N.; Qamar, S.H. The impact of hydrophilic emulsifiers on the physico-chemical properties, microstructure, water distribution and: In vitro digestibility of proteins in fried snacks based on fish meat. Food Funct. 2019, 10, 6927-6935. [CrossRef]

40. Yin, T.; He, Y.; Liu, L.; Shi, L.; Xiong, S.; You, J.; Hu, Y.; Huang, Q. Structural and biochemical properties of silver carp surimi as affected by comminution method. Food Chem. 2019, 287, 85-92. [CrossRef]

41. Shi, J.; Lei, Y.; Shen, H.; Hong, H.; Yu, X.; Zhu, B.; Luo, Y. Effect of glazing and rosemary (Rosmarinus officinalis) extract on preservation of mud shrimp (Solenocera melantho) during frozen storage. Food Chem. 2019, 272, 604-612. [CrossRef] [PubMed]

42. Walayat, N.; Xiong, Z.; Xiong, H.; Moreno, H.M.; Nawaz, A.; Niaz, N.; Hu, C.; Taj, M.I.; Mushtaq, B.S.; Khalifa, I. The effect of egg white protein and $\beta$-cyclodextrin mixture on structural and functional properties of silver carp myofibrillar proteins during frozen storage. LWT 2021, 135, 109975. [CrossRef]

43. Wang, W.; Shen, M.; Liu, S.; Jiang, L.; Song, Q.; Xie, J. Gel properties and interactions of Mesona blumes polysaccharide-soy protein isolates mixed gel: The effect of salt addition. Carbohydr. Polym. 2018, 192, 193-201. [CrossRef]

44. Chen, H.; Zou, Y.; Zhou, A.; Xiao, J.; Benjakul, S. Insight into the effect of ice addition on the gel properties of nemipterus virgatus surimi gel combined with water migration. Foods 2021, 10, 1815. [CrossRef] [PubMed] 
45. Sharma, S.; Majumdar, R.K.; Siddhnath, K.; Mehta, N.K.; Saha, A.; Gupta, S. Effects of Partial and Complete Replacement of Synthetic Cryoprotectant with Carrot (Daucus carota) Concentrated Protein on Stability of Frozen Surimi. J. Aquat. Food Prod. Technol. 2019, 28, 808-820. [CrossRef]

46. Zhang, B.; Fang, C.D.; Hao, G.J.; Zhang, Y. yang Effect of kappa-carrageenan oligosaccharides on myofibrillar protein oxidation in peeled shrimp (Litopenaeus vannamei) during long-term frozen storage. Food Chem. 2018, 245, 254-261. [CrossRef] [PubMed]

47. Kamińska-Dwórznicka, A.; Łaba, S.; Jakubczyk, E. The effects of selected stabilizers addition on physical properties and changes in crystal structure of whey ice cream. LWT 2022, 154, 112841. [CrossRef]

48. Kamińska-Dwórznicka, A.; Skrzypczak, P.; Gondek, E. Modification of kappa carrageenan by $\beta$-galactosidase as a new method to inhibit recrystallization of ice. Food Hydrocoll. 2016, 61, 31-35. [CrossRef]

49. Chen, X.; Wu, J.; Li, X.; Yang, F.; Yu, L.; Li, X.; Huang, J.; Wang, S. Investigation of the cryoprotective mechanism and effect on quality characteristics of surimi during freezing storage by antifreeze peptides. Food Chem. 2022, 371, 131054. [CrossRef]

50. Shen, X.; Li, T.; Li, X.; Wang, F.; Liu, Y.; Wu, J. Dual cryoprotective and antioxidant effects of silver carp (Hypophthalmichthys molitrix) protein hydrolysates on unwashed surimi stored at conventional and ultra-low frozen temperatures. LWT 2022, 153, 112563. [CrossRef] 